\title{
Strategi Pemberdayaan Ekonomi Pencari Kerja Usia Muda Berbasis Minat dan Sumber Daya Sosial Ekonomi Setempat pada Masyarakat Pesisir di Kota Makassar
}

\section{Economic Empowerment Strategy for Young Age Workers Based on Local Economic Resources and Social Resources In Coastal Communities in Makassar City}

\author{
Syamsuddin Simmau ${ }^{1}$; Susanti Mutia Lagaligo ${ }^{2 *}$ \\ 1.2 Universitas Sawerigading, Makassar \\ Email Coresponden: syamsuddinsimmau74@gmail.com ${ }^{1}$
}

\section{A R T I C L E I N F O}

\section{How to Cite:}

Simmau, S., \& Lagaligo, S. M. (2019). Strategi

Pemberdayaan Ekonomi

Pencari Kerja Usia Muda

Berbasis Minat dan Sumber

Daya Sosial Ekonomi

Setempat. Hasanuddin

Journal of Sociology (HJS),

1(2), 139-154.

\section{Keywords:}

Poverty, Empowerment,

Locality, Coastal

Communities.

\section{Kata Kunci :}

Kemiskinan, Pemberdayaan, Lokalitas, Masyarakat Pesisir.

\begin{abstract}
A B S T RA C T
Job creation to overcome unemployment and poverty should be the social responsibility of all parties, not just the government. This research aims to; (1) mapping the potential of socio-economic resources owned by the MOSA age group in coastal communities in Makassar City; (2) mapping the interest of young people in coastal communities in Makassar City in job creation; and (3) analyzing strategies for empowering young job seekers based on interests and socio-economic resources in coastal communities in Makassar City. The approach used in this research is a qualitative approach to the type of case study. This is done to obtain deeper qualitative data through in-depth interview techniques.

The results of research on young job seekers have understood some of the socioeconomic potential in their area. However, not yet fully understanding the existing social potential, so that potential cannot yet become "social capital" that can be transformed into economic resources. The paradigm of young job seekers is still the old paradigm, namely; the "worker" paradigm is not the business owner paradigm. Family involvement is an indicator of involving other social elements, such as; community leaders, religious leaders and employers, who can motivate young job seekers to have their own business or as an "entrepreneur" and not as a "worker".

In line with this, the strategy of empowering young job seekers is to increase the capacity of young job seekers through workshops; social mapping, strengthening the capacity for changing the paradigm of "entrepreneurship"; and workshops strengthening production, packaging and marketing skills.
\end{abstract}

\section{ABSTRAK}

Penciptaan lapangan kerja untuk mengatasi penganguran dan kemiskinan seharusnya menjadi tanggung jawab sosial semua pihak, bukan hanya 
pemerintah. Penelitian ini bertujuan untuk; (1) memetakan potensi sumber daya sosial ekonomi yang dimiliki oleh kelompok usia musa pada masyarakat pesisir di Kota Makassar; (2) memetakan minat kelompok usia muda pada masyarakat pesisir di Kota Makassar dalam penciptaan lapangan kerja; dan (3) menganalisis strategi pemberdayaan pencari kerja usia muda berbasis minat dan sumber daya sosial ekonomi pada masyarakat pesisir di Kota Makassar. Pendekatan yang digunakan dalam peneltian ini adalah pendekatan kualitatif jenis studi kasus. Hal ini dilakukan untuk memperoleh data kualitatif yang lebih mendalam melalui teknik wawancara mendalam.

Hasil penelitian pencari kerja usia muda telah memahami sebagaian potensi sosial ekonomi yang berada pada daerah mereka. Namun, belum memahami secara menyeluruh potensi sosial yang ada sehingga potensi tersebut tidak belum bisa menjadi "modal sosial" yang dapat ditransformasi menjadi sumber daya ekonomi.

Paradigma pencari kerja usia muda masih paradigma lama, yaitu; paradigma "pekerja" bukan paradigma pemilik usaha. Pelibatan keluarga merupakan indikator pelibatan elemen sosial lainnya, seperti; tokoh masyarakat, tokoh agama dan pengusaha, yang dapat memotovasi pencari kerja usia muda untuk memiliki usaha sendiri atau sebagi "pengusaha" dan bukan sebagai "pekerja".

Sejalan dengan hal tersebut maka strategi pemberdayaan pencari kerja usia muda adalah melakukan peningkatan kapasitas pencari kerja usia muda melalui workshop; pemetaan sosial, penguatan kapasitas perubahan paradigma "wirausaha"; dan workhsop penguatan keterampilan produksi, pengemasan dan pemasaran produksi.

\section{PENDAHULUAN}

Penanganan pengangguran merupa-kan sebuah keniscayaan yang sepatutnya dilakukan oleh pemerintah. Jika pengang-guran tidak ditangani dengan baik maka dapat menimbulkan masalah sosial seperti tingginya angka kriminalitas, konflik antar kelompok, dan meningkatnya jumlah penyandang masalah sosial (PMS) lainya. Data dalam Rencana Pembangunan Jangka Menengah Daerah (RPJMD) Provinsi Sulawesi Selatan tahun 2013- 2018 menunjukkan bahwa jumlah pengangguran mencapai 208.983 jiwa pada tahun 2012. Pada tahun yang sama, jumlah pencari kerja usia 15-19 tahun sebanyak 48.477 jiwa, usia 20-24 tahun berjumlah 64.538 jiwa, usia 30-34 tahun berjumlah 18.822 jiwa, usia 3539 tahun yang mencari kerja sebanyak 14.232 jiwa, dan pencari kerja usia 40-44 tahun berjumlah 11.494 jiwa. Data tersebut menunjukkan bahwa angkatan kerja usia muda masih banyak yang menjadi beban masyarakat dan beban negara.

Jumlah pengangguran yang dipandang masih sangat besar tersebut berpotensi menjebak para pengangguran dan "kondisi kemiskinan" yang berkepanjangan. Oleh karena itu, perlu dirumuskan langkah-langkah strategis untuk membantu mencari solusi dalam mengani masalah pengangguran di daerah Sulawesi Selatan.

Penanganan masalah pengangguran ini dapat dimulai dari masyarakat pesisir. Hal ini penting 
dilakukan karena masyarakat Sulawesi Selatan adalah mayoritas masyarakat pesisir. Karena itu cukup beralasan jika penangnana pengangguran, khususnya pemuda putus sekolah pada masyarakat pesisir mendapat perhatian serius.

Salah satu cara yang dapat dilakukan adalah penguatan masyarakat lokal dengan memaksimalkan pengelolaan potensi sumber daya lokal. Penghargaan terhadap lokalitas semestinya bukan sekadar slogan dan jargon sehingga kaum kapitalis, khususnya kapitalis global tidan menjadi penguasa tunggal atas dominasi ekonomi. Karena kenyataan menunjukkan bahwa di balik keterbelakangan ekonomi masyarakat, khususnya masyarakat pesisir, memiliki kemampuan untuk mengembangkan diri menjadi masyarakat yang mampu memaksimalkan potensi sumber daya lokal menjadi usaha produktif yang mendukung peningkatkan kesejahteraan. Menurut pandangan Sallatang (1982), masyarakat bahari memiliki pengetahuan, gagasan, keyakinan/kepercayaan, nilai, dan norma/aturan dan pengenalan lingkungan sosialnya berkenaan dengan pemanfaatan sumberdaya dan jasa-jasa laut. Hal ini menjadi energi bagi masyarakat bahari dalam mengelola kehidupan mereka.

Bagaimana dengan penanganan masyarakat pesisir, khususnya kelompok usia muda, yang merupakan bagian integral dari masyarakat maritim yang bermukim di kota ? Apakah penanganannya juga harus berbasis pada sumber daya laut ? Tentu saja hal ini mejadi rumit karena tidak semua masyarakat pesisir, khususnya kelompok usia muda (15-35 tahun) yang berminat pada sumber kehidupan dari laut.

Terdapat beberapa konsep yang dapat menjadi landasan pembahasan penelitian ini, yaitu: Kemiskinan, Pemberdayaan, Lokalitas dan Pemberdayaan Masyarakat Pesisir.

\section{- Konsep Kemiskinan}

Masyarakat pesisir, khususnya nelayan pada beberapa daerah identik dengan kemiskinan. Kemiskinan ini disebabkan oleh kondisi internal dan eksternal masyarakat. Kondisi internal bisa jadi disebabkan oleh rendahnya motivasi serta keterbatasan pendidikan dan keterampilan. Sementara, secara eksternal bisa jadi disebabkan oleh sistem pemerintahan maupun sistem pasar dan budaya.

Motivasi yang rendah untuk meningkatkan akses atas kepemilikan modal, akses atas pasar dan saran produkti sangat dipengaruhi oleh impuls yang mendorong seseorang melakukan suatu tindakan sosial. Max Weber (Johnson, 1986) menegaskan bahwa akar motivasi individu jauh lebih dalam dari pada keputusan rasional yang disengaja mengenai alat dan tujuan atau komfimitas terhadap tuntutan dari mereka yang beriorentasi. Bagi Weber agama dan nilai sangat menentukan pola motivasional seseorang dalam tindakan ekonominya.

Dalam hal ini kemiskinan yang dimaksud adalah kemiskinan menurut Soekanto (2009) yang mengartikan kemiskinan sebagai suatu kondisi dimana seseorang tidak sanggup memelihara dirinya 
sendiri sesuai dengan taraf kehidupan kelompok dan juga tidak mampu memanfaatkan tenaga, mental maupun fisiknya dalam kelompok tersebut. Pandangan ini menunjukkan bahwa kemiskinan terkait dengan adanya ketidak mampuan memanfaat sumber daya, baik sumber daya alam maupun sumber daya manusia si miskin sebagaimana yang mampu dilakukan oleh masyarakat yang tidak miskin.

Sementara itu, David Cox (Suharto, 2010) yang membagi kemiskinan ke dalam berbagai dimensi, yaitu: Pertama, kemiskinan yang diakibatkan globalisasi. Globalisasi menghasilkan pemenang dan yang kalah. Umumnya pemenang adalah negara-negara maju dan yang kalah adalah negara-negara berkembang. Kedua, kemiskinan yang berkaitan dengan pembangunan. Hal ini menunjukkan bahwa pembangunan tidak hanya berdampak posisitf tapi juga membawa dampak negatif. Penggusuran tanpa solusi akan menggiring masyarakat tergusur pasa kondisi yang termarginalkan. Bahkan mereka berpotensi kehilangan sumber daya utama. Misalnya, seorang petani yang awalnya memiliki sebidang tanah sawah yang menjadi tumpuan ekonomi keluarga tiba-tiba tidak memiliki harta lagi karena si petani menjual sawah mereka untuk kepentingan pembangunan pabrik. Ketiga, selain bentuk kemiskinan tersebut ada pula bentuk kemiskinan yang disebut kemiskinan sosial. kemiskinan jenis ini umumnya dialami oleh perempuan, anak-anak dan kelompok minoritas. Dalam hal ini, kelompok perempuan dan kelompok lemah laninya menjadi miskin karena mereka dicitrakan sebagai kelompok yang kurang memiliki akses atas modal dan sumber-sumber produksi. Kelompok perempuan dicitrakan secara sosial berada pada wilayah domestik saja sehingga mereka kurang memiliki akses atas kekayaan. Demikian halnya dengan kelompok marginal lain, seperti kelompok masyarakat berkebutuhan khusus. Mereka dianggap tidak mampu melakukan berbagai hal terkait dengan produktifitas yang bernilai ekonomis sehingga mereka hidup tergantung, lalu miskin. Keempat, kemiskinan konsekuensial, yaitu kemiskinan yang menjadi akibat dari kejadian- kejadian lain atau faktor-faktor eksternal di luar si miskin, seperti koflik, bencana alam, kerusakan lingkungan dan tingginya jumlah penduduk.

Konsep kemiskinan lainnya dapat dilihat pada pandangan Ellis yang mengemukakan bahwa kemiskinan menyangkut berbagai dimensi seperti ekonomi, politik dan sosial psikologis. Secara eknomi, kemiskinan didefinisikan sebagai kekurangan sumber daya yang dapat digunakan untuk mempengaruhi kebutuhan hidup dan meningkatkan kesejahteraan sekelompok orang. Secara politik, kemiskinan dapat dilihat dari tingkat akses terhadap kekuasaan. Dan kemiskinan secara sosio psokologis menunjuk pada kekuarangan jaringan dan struktur sosial yang mendukung dalam mendapatkan kesempatan-kesempatan peningkatan produktifitas. Karena itu, untuk membawa si lemah, miskin dan termarginalkan, baik secara ekonomi, politik maupun sosio-psikologis maka perlu dilakukan pemberdayaan sehingga mereka memiliki kekuasaan untuk membawa diri mereka ke arah yang lebih berdaya. Tentu saja, proses menuju keberdayaan tersebut membutuhkan intervensi dan strategi yang 
menunjang kelompok rentan dan marginal tadi untuk keluar dari persoalan yang melekat pada diri mereka secara kultural dan struktural (Suharto, 2010).

\section{- Pemberdayaan dan Mencapai Pemberdayaan}

Menurut Ife \& Toseriero (2008), pemberdayaan tidak bisa dilepaskan dengan kekuasaan. Karena itu, pemberdayaan kiranya dapat ditinjau dari berbabagi perspektif, yaiti; perspektif pluralis, perspektif elite, perspektif struktural dan perspektif post- struktutal. Menurut pandangan pluralis, pemberdayaan merupakan suatu proses menolong kelompok atau individu yang dirugikan untuk bersaing secara lebih efektif dengan kepentingan-kepentingan lain, dengan menolong mereka untuk belajar dan menggunakan keterampilan-keterampilan dalam melobi, menggunakan media, melakukan aksi politik, memahami bagaimana memanfaatkan sistem, dan sebagainya.

Sedangkan menurut perspektif elite, masyarakat dipandang memiliki hirarkhi dengan kelompok-kelompok tertentu dalam menjalankan kekuasaan dan kontrol. Dalam hal ini, pemberdayaan dinilai lebih dari sekedar memiliki kemampuan berkompetesi untuk kekuasaan politik dengan memainkan permainan; aturan main yang telah ditetapkan oleh elite pengusaha dan karena itu cenderung akan menguntungkan mereka.

Sementara itu, perspektif struktural memandang pemberdayaan sebagai agenda yang jauh lebih menantang, karena hal itu hanya dapat dicapai secara efektif jika bentuk-bentuk struktur yang merugikan ditantang dan diatasi. Karena itu, pemberdayaan, selalu merupakan bagian dari program perubahan sosial yang lebih luas, dengan pandangan untuk melucuti struktur-struktur opresif yang dominan.

Lain halnya dengan perspektif post-struktutal. Pandangan ini mengacu pada Foucault (1973, 1979; Rouse, 1984) yang melacak cara-cara berbagai gagasan, bahasa, dan definisi pengetahuan telah digunakan sebagai suatu mekanisme kontrol yang utama. Perspektif ini memandang pemberdayaan sebagai suatu proses menantang dan mengubah wacana. Ia menekankan pengertian-pengertian subjektif manusia dan konstruksi pandangan dunia mereka, dan menunjuk kepada kebutuhan untuk mendekonstruksi pengertian-pengertian ini dan pembentukan suatu kosa kata alternatif untuk pemberdayaan. Dengan demikian, perspektif post-struktural ini menegaskan mengenai pentingnya pengertian, analisis, dekonstruksi, pendidikan dan partisipasi dalam wacana-wacana kekuasaan, dan melihat suatu konsentrasi pada aksi saja sebagai tidak mencukupi (Ife \& Toseriero (2008).

Selain Ife dan Toseriero, Suharto (2010) mengemukakan bahwa pemberdayaan atau pemberkuasaan (empowerment) berasal dari kata power (kekuasaan atau keberdayaan). Karenya, ide utama pemberdayaan bersentuhan dengan konsep mengenai kekuasaan. Karena itu, pemberdayaan merujuk pada kemampuan orang, khususnya kelompok rentan dan lemah, sehingga mereka memiliki 
kekuatan atau kemampuan dalam memenuhi kebutuhan dasarnya sehingga mereka memiliki kebebasan dari kelaparan, bebas dari kebodohan dan bebas dari kesakitan. Selain itu, mereka juga mampu menjangkau sumber- sumber produktif yang memungkinkan mereka dapat meningkatkan pendapatannya dan Memperoleh barang-barang dan jasa-jasa yang mereka perlukan. Poin yang tidak kalah pentingnya adalah bahwa kekuasaan tersebut dapat membawa kelompok marginal keluar dari kondisi ketermarginalan mereka menuju pada kemampuan untuk berpartisipasi dalam proses pembangunan dan keputusan-keputusan yang mempengaruhi mereka.

Sementara itu, Parson mengatakan bahwa pemberdayaan adalah sebuha proses dengan mana orang menjadi cukup kuat untuk berpartisipasi dalam berbagai pengontrolan atas, dan mempengaruhi terhadap, kejadian-kejadian serta lembaga-lembaga yang mempengaruhi kehidupan-nya. Pemberdayaan menekankan bahwa orang memperoleh keterampilan, penge-tahuan, dan kekuasaan yang cukup untuk mempengaruhi kehidupannya dan kehi-dupan orang lain yang menjadi perhatian-nya Suharto (2010).

Sementara itu, Kartasasmita (1995) mengemukakan bahwa upaya member-dayakan harus dilakukan melalui tiga cara, yaitu; membuat suasana atau iklim yang memungkinkan potensi masyarakat untuk berkembang, memperkuat potensi yang dimiliki oleh rakyat dengan menerapkan langkah-langkah nyata, menampung berbagai masukan, menyediakan prasarana dan sarana, maupun sosial (sekolah dan fasilitas kesehatan) yang dapat diakses oleh masyarakat lapisan bawah, dan memberdayakan rakyat dalam arti melindungi dan membela kepentingan masyarakat lemah (Hidayat, 2013). Terkait dengan diskursus kemiskinan dan pemberdayaan David Cox telah menegaskan bahwa kemiskinan selalu menjadi indikator kunci untuk melakukan pemberdayaan itu (Suharto, 2010). Pendapat ini seakan-akan menegaskan bahwa alasan dilakukannya pemberdayaan adalah karena adanya kemiskinan. Padahal ada kondisi lain yang mengharusnya dilalukakannnya pemberdayaan. Patut ditelaah secara kritis bahwa pemberdayaan tidak hanya terkait dengan kemiskinan tapi juga terkait dengan marginalisasi. Dalam beberapa kasus, komunitas ada keluarga kaya yang mengalami marginalisasi, seperti kelompok perempuan, anak dan kelompok difabel. Perempuan dan anak dalam keluarga kaya bisa jadi merupakan kelompok yang terintimidasi secara sosial dan ekonomi. Mereka hanya menjadi kelas kedua dalam keluarganya. Karena itu, dalam kasus seperti ini perlu dilakukan pemberdayaan. Pembedayaan dalam konteks ini, tentu saja tidak hanya dilakukan terjadap kelompok yang dimarginalisasi tapi juga kepada kelompok yang melakukan marginalisasi. Sebab, pemberdayaan tidak cukup hanya dengan "merebut" keberdayaan tapi yang paling penting adalah kesadaran untuk memberi ruang dan kesempatan keberdayaan kepada setiap orang, termasuk bagi anggota keluarga. Karena itu, prinsip pemberdayaan semestinya merujuk pada azaz kemanusiaan yang berdaya, yaitu 
manusia (laki-laki, perempuan, anak-anak dan orang tua, kelompok difabel dan penyandang masalah sosial) adalah manusia yang memiliki kesempatan dan hak yang sama untuk memperoleh prinsip kemerdekaan sebagai manifestasi dari ide absolut dari keberdayaan itu.

\section{- Lokalitas}

Pemberdayaan masyarakat hendaknya tidak lagi mengacu pada paradigma bahwa ada kondisi masyarakat yang tidak berdaya sementara pada sisi lain ada sekelompok orang yang "merasa" telah berdaya dan karenanya mampu melakukan pemeberdayaan.

Pemberdayaan model ini jelas menempatkan kelompok masyarakat yang tidak berdaya sebagai masyarakat yang tersubordinasi, dan oleh karenanya mereka akan mengikuti desain pemberdayaan menurut "kelompok pembedaya". Pem-bedayaan yang menggunakan paradigma ini merupakan paradigma "pembangunanisme" atau developmentalisme yang terbukti sampai saat ini, pada banyak kasus, belum mampu membawa masyarakat "kurang berdaya" menjadi masyarakat berdaya.

Oleh karena itu, paradigma hendanya diubah menjadi paradigma co-evolusif yang mengandung makna sebagai pembedayaan bersama menuju perubahan bersama. Pada gejala ini, baik "pembedaya" maupun "yang diberdayakan" sama-sama melakukan proses pembelajaran untuk mencapai keberdayaan bersama. Prinsip ini jelas mengacu pada prinsip "humanitas" untuk semua. Dengan demikian, aspek dan potensi lokal sangat dihargai, bahkan mejadi energi utama, untuk melakukan perubahan yang lebih baik seiring dengan nilai-nilai global yang relevan dengan aspek dan nilai-nilai lokal tersebut. Hal ini sejalan dengan pandangan Ife dan Toseriero (2008) yang mengemukakan prinsipprinsip dasar pengembangan masyarakat, sebagai berikut:

1. Ide dan pengalaman masyarakat sangat penting untuk mencapai kemanusiaan mereka secara penuh.

2. Prinsip-prinsip kelangsungan ekologis, holisme, keseimbangan dan lainnya.

3. Prinsip-prinsip keadilan sosial dan hak azazi manusia termasuk analisis penindasasn (kelas, gender, ras/suku, dan lainnya).

4. Prinsip-prinisp perubahan dari bawah, menghargai pengetahuan dan keterampilan lokal.

5. Sentralitas partisipasi warga.

6. Prinsip-prinsip integritas proses, peningkatan kesadaran, pemberdayaan, kesadaran dan lainnya.

Prinsip-prinsip umum di atas berlaku untuk semua pengembangan masyarakat, dalam konteks apapun. Bahkan, Camfens (1997) dan Kenny (1999) menegaskan pentingnya kon-tektualisasi prinsipprinsip tersebut secara berbeda-beda di lokasi-lokasi yang berbeda pula. Hal ini menunjukkan bahwa 
pengalaman masyarakat meru-pakan hal yang paling penting di wilayah manapun (Ife dan Toseriero, 2008).

Pada paradigma perubahan ber-sama menuju keberdayaan bersama merupakan landasan fundamental para-digma pember-dayaan partisipatif atau pemberdayaan yang mendorong peru-bahan dari bawah. Karena itu, telah menjadi keniscayaan bahwa prinsip- prinsip perubahan dari bawah berpusat pada gagasan tentang penghargaan lokal, dan bukan mengistimewakan penge-tahuan, keterampilan, proses dan sumber daya yang dipaksakan terhadap masyarakat dari atas.

Eksistensi lokalitas dapat dilihat secara prinsipil pada model perubahan dari bawah. Dengan demikian, ada beberapa poin mendasar yang patut mendapat apresiasi dalam melakukan pengembangan masyarakat menurut Ife dan Toseriero (2008), yaitu:

1. Menghargai pengetahuan lokal;

2. Menghargai budaya lokal;

3. Menghargai sumber daya lokal;

4. Menghargai keterampilan masyarakat lokal;

5. Menghargai proses lokal;

6. Menghargai partisipasi masyarakat (termasuk gender).

Dengan demikian, jelaslah bahwa pemberdayaan masyarakat menuju keber-dayaan yang hakiki harus menge-depankan sinkronistas atas nilai lokal dan global, kebutuhan masyarakat lokal dan global, serta akses dan pemanfaat sumberdaya lokal untuk masyakat lokal dan mayarakat global. Sehingga lokalitas dan globalitas bukan lagi dua hal yang harus dikotomisasi karena lokalitas dan globalitas sesung-guhnya dua sisi mata uang "materil" yang tak dapat dipisahkan. Jika tidak demikian, maka globalitas akan menghegemoni lokalitas yang pada gilirannya hanya akan menggiring masyarakat lokal pada kondisi "dehumanisasi".

\section{- Pemberdayaan Masyarakat Pesisir}

Menurut Salman (2011), masyarakat maritim adalah prototipe masyarakat yang jauh tertinggal dibanding komunitas darat yang telah menetapkan pertanian sebagai arus utama transformasinya. Bagi Salman potret ketertinggalan merupakan narasi besar jagad maritim Indonesia.

Sementara itu, Burchanuddin dkk. (2013) mengemukakan realitas kehidupan nelayan Kajuara Kabupaten Bone, Sulawesi Selatan. Penelitian Burhanuddin menun-jukkan bahwa terdapat perbedaan yang signifikan antara taraf hidup nelayan lokal yang hanya memiliki alat tangkap tradisional dengan nelayan lokal yang menggunakan alat tangkap modern.

Lagi halnya dengan kasus nelayan di Buton. Tenri dan Munafi (2013) mengemukakan bahwa telah 
terjadi polarisasi pasar lokal dan global di Buton. Sehingga masyarakat nelayan terposisikan pada sisi nihil proteksi. Ketimpangan sosial ekonomi terjadi bahkan cenderung melebar karena surplus produksi hanya dinikmati oleh pemilik modal.

Berangkat dari proposisi di atas maka masyarakat pesisir sebagai salah satu entitas masyarakat maritim memerlukan strategi yang dapat membawa mereka pada kondisi keberdayaan. Burchanuddin dkk. (2013) menawarkan pentingnya penerapan teknologi bagi nelayan tradisional untuk meningkatkan kesejahteraan mereka. Sementara Tenri dan Munafi (2013) menawarkan gagasan kemitraan pekerjapengusaha pada sektor maritim dan membuka peluang diversifikasi usaha maritim. Selain, juga diusulkan agar dilakukan re-regulasi sektor perbankan agar mendukung usaha sektor maritim. Lain halnya dengan Rosmawati (2013) yang mengusulkan agar dilakukan penguatan kelembagaan untuk mengawal pengem-bangan sumber daya nelayan pancing yang masih rendah. Sementara itu, Bastiana (2013) menegaskan pentingnya pendidikan kecakapan hidup bagi perempuan di daerah pesisir.

Berdasarkan beberapa argumentasi di atas maka setidaknya dikemukakan beberapa upaya pemberdayaan masyarakat pesisir, yaitu:

1. Pendidikan kecakapan hidup bagi masyarakat pesisir,

2. Penerapan teknologi,

3. Kemitraan pekerja-majikan,

4. Diversifikasi usaha bidang maritim,

5. Pembukaan akses permodalan

6. Proteksi pasar bagi nelayan lokal untuk menghindari polarisasi pasar global-lokal.

7. Regulasi yang berpihak pada masyarakat maritim.

Berdasarkan deskripsi di atas, maka penting dilakukan langkah-langkah strategis, yaitu; melakukan penggalian potensi sumber daya sosial ekonomi dan sumber daya manusia yang berdasar pada minat. Dengan demikian, angka pencari kerja usia muda dan pengangguran akan berkurang seiring dengan meningkatnya lapangan kerja yang lahir dari pengembangan minat dan potensi sumber daya sosial ekonomi lokal yang dimiliki. Di sinilah letak peran strategis penelitian ini. Dengan demikian, penelitian mengenai Strategi Pemberdayan Ekonomi Pencari Kerja Usia Muda Berbasis Minat dan Sumber Daya Sosial Ekonomi Setempat pada Masyarakat Pesisir Di Kota Makassar bersifat urgen. Sehingga, masyarakat Kota Makassar, khususnya pencari kerja usia muda dapat merubah pola perilaku mereka dari mencari kerja menjadi "pencipta kerja".

\section{METODE PENELITIAN}


Pendekatan penelitian yang digunakan dalam penelitian ini adalah kualitatif jenis studi kasus. Penelitian ini dilakukan di Kelurahan Lette Kecamatan Mariso Kota Makassar, Kelurahan Untia Kecamatan Biringkanaya Kota Makassar, dan Kelurahan Balang Baru Kecamatan Tamalate Kota Makassar pada Juli sampai September 2018. Penentuan lokasi penelitian ini berdasar pada letak geografis lokasi yang berada di pesisir Kota Makassar. Penelitian ini dilaksanakan selama 6 (enam) bulan (lihat Jadwal Penelitian terlampir).

\section{HASIL PENELITIAN DAN PEMBAHASAN}

Hasil penelitian ini diolah dari dua jenis instrumen, yaitu panduan observasi dan pandauan wawancara mendalam. Observasi dilakukan lebih awal dari wawancara. Hal ini disebabkan karena Surat Izin Penelitian terlambat diterbitkan oleh Dinas Penanaman Modal dan Pelayanan Terpadu Satu Pintu Porivinsi Sulawesi Selatan (Dinas PMPTSP Sulsel, dulu disebut juga BKPMD) karena terjadi kerusakan sistem Informasi dan Teknologi (IT) pada instansi yang berwenang menerbitkan izin penelitian tingkat provisni. Meski demikian, proses observasi sudah berjalan sejak 25 Juni 2018. Hal ini mengacu pada Surat Permohonan Izin Penelitian dari Ketua Lembaga Penelitian dan Pengabdian pada Masyarakat (LPPM) Universitas Sawerigading (Unsa) Makassar tertanggal 19 Juni 2018 yang ditujukan kepada BKPMD Provinsi Sulsel. Sementara itu, wawancara mendalam dilakukan setelah izin resmi diterbitakn Dinas PMPTSP Sulsel yang ditujukan kepada Pemerintah Kota Makassar, tertanggal 18 Juli 2018. Selanjutnya izin tersebut ditindak lanjuti hingga tingkat kecamatan dan kelurahan tempat penelitian ini dilaksakan.

\section{- Potensi Sumberdaya Sosial Ekonomi}

Berdasarkan observasi tidak turut serta yang dilakukan pada 25 dan 26 Juni 2018 di Kelurahan Lette, diketahui bahwa terdapat beberapa potensi sosial ekonomi di daerah ini yang dapat dimanfaatkan oleh pencari kerja usia muda untuk meningkatkan taraf kehidupan ekonomi mereka. Beberapa potensi sosial ekonomi tersebut adalah:

a. Pada Lorong 9 terdapat pusat pengrajin rotan.

b. Kelurahan lette berdekatan dengan Pelelangan Ikan Rajawali Kota Makassar.

c. Terdapat kelompok karang taruna Kelurahan Lette

d. Ikatan sosial berupa kegiatan majelis taklim dan pengajian juga terdapat di kelurahan ini.

e. Solidaritas sosial masih terjaga ditandai dengan masih dilakukannya aksi gotong royong yang dipelopori oleh pemerintah kelurahan dan tokoh masyarakat.

f. Kelurahan ini berdekatan dengan Tempat Pelelangan Ikan Rajawali Kota Makassar. 
g. Berbatasan dengan Pantai Losari sebagai daerah wisata Kota Makassar.

h. Potensi pasar besar karena daerah ini adalah daerah padat penduduk.

i. Aktifitas pedagang kecil tampak aktif di daerah ini.

Sementara itu, observasi pertama dan observasi kedua yang dilakukan pada 20 dan 21 Juli 2018 di Kelurahan Untia Kecamatan Biringkanaya Kota Makassar juga terdapat potensi sosial sosial ekonomi yang dapat menjadi sumber ekonomi pencari kerja usia muda. Beberapa potensi sosial tersebut adalah:

a. Kelurahan Untia telah ditetapkan sebagai kawasan wisata.

b. Terdapat pelabuhan pendaratan ikan Kota Makassar.

c. Terdapat SMK Negeri 9 Kota Makassar.

d. Terdapat Kampus Politeknik Ilmu Pelayaran (PIP).

e. Berdekatan dengan pusat pergudangan Kawasan Industri Makassar.

f. Pelaksanaan Pelatihan Wirausaha oleh Karang Taruna Kelurahan Untia.

g. Potensi Hutan Bakau sebagai objek wisata dan ternak kepiting bakau.

h. Potensi Rumah Kost dan Cottage untuk wisatawan lokal terbuka luas.

i. Potensi kuliner

j. Solidaritas masyarakat, khususnya dalam bidang keagamaan masih terpelihara dengan baik sebagai modal sosial.

Sementara itu, berdasarkan wawancara mendalam di Kelurahan Untia Kecamatan Biringkanaya Kota Makassar yang dilakukan pada 31 Juli 2018 dan 3 Agustus 2018 maka dapat diidentifikasi bebepara potensi yang diketahui informan.

a. Informan pertama (JSRD, laki-laki, $21 \mathrm{thn}$ ) mengemukakan bahwa ia mengetahui beberapa potensi yang berada pada daerahnya, yaitu:

b. Dekat dengan Pusat Kawasan Industri Makassar (PT.Kima),

c. Pelabuhan pendaratan ikan.

d. Kampung wisata.

e. Kampus PIP

f. Karang Taruna

Menurut informan pertama ini, ia tidak mengetahui potensi lain yang ada di daerhnya selain yang ia telah sebutkan. Menurutnya, kedekatan kelurahan Untia dengan PT Kima terbukti telah memberi peluang kepada anak muda yang telah lulus SMA atau SMP untuk bekerja di pergudangan sebagai karyawan.

Demikian, halnya dengan pelabuhan pendaratan ikan juga menyerap beberapa tenaga kerja 
muda di daerah ini. Sementara kampung wisata juga dinilai telah memberi peluang bagi sanggar seni yang dikelala masyarakat setempat untuk mendapatkan penghasilan. Hanya saja potensi tersebut belum maksimal menyerap angkatan kerja usia muda.

Sementara itu, kampus keberadaan kampus PIP telah menyerap beberapa anak muda menjadi karyawan di perguruan tinggi bidang pelayaran ini. Umumnya, tenaga kerja yang diserap masih pada posisi pegawai biasa bahkan pegawai kontrak saja.

Sejalan dengan itu, Karang Taruna juga dinilai memberi kesempatan kepada generasi muda untuk berkembang dengan diadakannya pelatihan kewirausahaan. Hanya saja, masih perlu dilakukan pelatihan karena setelah selesai pelatihan, tenaga kerja muda masih memiliki menjadi karyawan di beberapa tempat dibandingkan dengan menjadi usahawan muda (wawancara, 31 Juli 2018).

Sementara itu, (SN JMRT-perempuan, 18 thn), yang diwawancara pada 3 Agustus 2018, mengemukakan bahwa dirinya tidak pernah berpikir untuk menjadi pegawai negeri. Jadi setelah tamat SMA, ia meneruskan usaha keluarganya. Motivasinya datang dari ibunya yang telah menjadi penguhaha katering dengan model home industri. Dari usaha inilah ibu informan kedua ini bisa membele mobil dan aset lainnya. Dengan melihat usaha ibunya maka informan yakin memilih membuka usaha sendiri.

Meski berharap menjadi pengusaha, informan kedua ini belum mengetahui beberapa potensi yang dimiliki daerahnya sebagai potensi sosial ekonomi, seperti potensi hutan mangrove, rumah kost atau cottage dan solidaritas masyarakat. Menurutunya, ia belum berpikir bahwa potensi tersebut bisa menjadi potensi sosial ekonomi.

Sementara itu, informan di Kelurahan Lette, (ANT, 21 thn) yang diwawancara pada 7 Agustus 2018 mengemukakan bahwa ia mengetahui beberapa potensi sosial ekonomi di daerah, seperti; ada pusat pengrajin rotan, dekat dengan Pelelangan Ikan Rajawali Kota Makassar (lelong, bahasa setempat), dan berdekatan dengan Pantai Losari. Tapi ia tidak mengetahui potensi lainnya.

Informan ini juga mengaku bahwa ia tidak mengetahui cara untuk mengelola potensi sumber daya ekonomi yang ada menjadi sumber daya ekonomi potensia. Yang ia ketahui hanya potensi berdagang (kaki lima) yang telah dilakukan sebagian temannya sesama anak muda di Pantai Losari dan menjadi tenaga penjual atau buruh ikan di lelong (pelelangan ikan).

Hal senada dekemukakan informan kedua di kelurahan Lette (ASN,perempuan, 20 thn) yang diwawancara pada 9 Agustus 2018. Menurut ASN, ia mengetahui bahwa bahwa ada pusat kerajinan rotan, keberadaan pantai lisari sebagai tempat berjualan dan lelong sebagai tempat bekerja sebagai penjual ikan atau buruh angkut ikan. Semua pekerjaan tersebut menurut ASN didominasi oleh laki-laki dan ibu-ibu, tidak anak muda putri.

Tapi, ASN tidak mengetahui potensi lain selain pedangang kaki lima dan buruh kerja. Demikian halnya dengan keberadaan karang taruna masih dinilai ASN sebagai tempat belajar organisasi, ia belum mengetahui bahwa karang taruna bisa menjadi wadah pengembangan kewira-usahaan generasi muda. Bahkan, ia tidak memahami bahwa soslidaritas masyarakat, 
sepeti pengajian, arisan dan bentuk gotong royong sebagai potensi sosial ekonomi.

ASN juga mengaku bahwa pelatihan yang biasa dilakukan sebatas pelatihan keterampilan masak memasak dan keterampilan lain, yang menurutnya belum bisa dijadikan sebagai penghasilan yang memadai.

Berdasar pada data di atas, perlu ditegaskan bahwa secara substansial informan memiliki pemahaman tentang potensi sumber daya sosial ekonomi setempat secara formal belaka, belum memahami potensi sumber daya sosial berupa sosildaritas dan transformasi pengelolaan sumber daya sosial ekonomi secara produkti.

Pada kasus, Untia misalnya, semestinya informan memahami bahwa potensi hutan mangrove sebagai potensi sumber daya ekonomi baik dari aspek wisata mangrove maupun sebagai potensi budidaya kepiting yang memiliki nilai ekonomi tinggi. Selain itu, cottage merupakan sarana wisata yang akan menyerap tenaga kerja yang besar. Demikian halnya pengelolaan industri produk pengolahan ikan, dimana pelabuhan pendaratan ikan berada dilokasi ini. Tentulah, hal ini memiliki potensi yang besar untuk aneka produk kuliner seperti bakso ikan, keripik ikan, dan aneka penganan lainnya dari potensi perikanan.

Informan juga belum mengetahui tentang potensi pasar, misalnya, kepadatan penduduk, sekolah, kampus dan struktur lainnya merupakan pasar yang potensial untuk memasarkan produk hasil industri. Hal ini disebabkan karena belum ada pengetahuan tentang pengelolaan potensi pasar potensi yang dekat dengan produksi.

Dengan demikian, diperlukan pemetaan potensi sosial ekonomi lokal dan cara transformasi potensi tersebut menjadi sumber daya ekonomi yang dapat mem-bantu pencari kerja usia muda untuk membangun usahanya. Hal ini menun-jukkan bahwa dibutuhakn pengetahuan mendasar tentang semangat kewirausahaan kepada para pencari kerja usia muda, sehingga tidak lagi berorientasi pada "mencari kerja” tapi berorienstasi pada "penciptaan lapangan kerja'.

Orientasi penciptaan lapangan kerja ini merupakan fenomena yang terbukti bisa diwujudkan. Terbukti, bahwa informan, di Untia memiliki kesadaran kewirausahaan karena adanya keterlibatan keluarga dalam memberi motivasi. Indikator keterlibatan keluarga ini merupakan kunci bagi potensi sumber daya sosial lainnya, misalnya potensi kegotongroyongan dan kepedulian semestinya ditransformasi menjadi kego-tongroyongan dan kepedulian tokoh masyarakat dan tokoh agama pada pengembangan ekonomi pencari kerja usia muda. Sehingga, persoalan pengangguran, tidak lagi menjadi beban pemerintah semata tapi juga menjadi tanggung jawab sosial setiap elemen masyarakat.

\section{- Minat Pencari Kerja Usia Muda dalam Penciptaan Lapangan Kerja}

Berdasarkan wawancara pada informan, diketahui bahwa pencari kerja usia muda masih 
berminat pada pekerjaan formal di pabrik dan lembaga atau instansi; baik instansi negri maupun swasta. Hal ini bermakna bahwa mental pencari kerja usia muda masih sebagai "pekerja” bukan sebagai pemiliki usaha.

Meski demikian, keterlibatan sosial keluarga dalam memberi motivasi dan contoh kepada generasi muda terbukti dapat menularkan semangat "pemilik usaha" dari pada menjadi pekerja. Dengan demikian, keterlibatan unsur sosial memang diperlukan, tidak hanya memberi peningkatan keterampilan teknis tapi "keterampilan khsusus, filosofis" tentang pentingnya menjadi "pemiliki usaha" bukan sebagai "pekerja" pada usaha atau bidang pekerjaan tertentu saja.

- Strategi Pemberdayaan Pencari Kerja Usia Muda Berbasis Minat dan Sumber Daya Sosial Ekonomi Menurut Pencari Kerja Usia Muda

Berdasar pada data sebagaimana di deskripsikan di atas maka dapat dirumuskan strategi pemerdayaan pencari kerja usia muda berbasi potensi sosial ekonomi setempat sebagai berikut:

a. Identifikasi potensi sumber daya sosial ekonomi,

b. Deskripsikan potensi sumber daya sosial sebagai modal sosial untuk pengembangan ekonomi,

c. Lakukan pemetaan potensi sumber daya sosial ekonomi,

d. Lakuktan penguatan kapasistas pencari kerja usia muda dari aspek filosofis, psikologis dan sosiologis.

e. Lakukan penguatan kemampuan transformasi sumber daya sosial menjadi sumber daya ekonomi.

f. Lakukan pelibatan keluarga dan potensi sosial seperti tokoh agama, tokoh masyarakat dan pengusaha dalam mendorong paradigma baru "kewi-rausahaan berbasis potensi sosial" menjadi potensi ekonomi.

g. Gunakan potensi sosial seperti kegotong royongan, keagamaan dan kedermawanan sebagai jaringan.

h. Lakukan penguatan kapasitas skill (keterampulan teknis) dalam produksi, pengemasan produk dan pembukaan akses pasar.

\section{KESIMPULAN}

Kesimpulan yang dapat ditarik dari penelitian ini adalah bahwa pencari kerja usia muda telah memahami sebagaian potensi sosial ekonomi yang berada pada daerah mereka. Namun, belum memahami secara menyeluruh potensi sosial yang ada sehingga potensi tersebut tidak belum bisa menjadi "modal sosial" yang dapat ditransformasi menjadi sumber daya ekonomi. Paradigma pencari kerja usia muda masih paradigma lama, yaitu; paradigma "pekerja" bukan paradigma pemilik usaha. 
Pelibatan keluarga merupakan indikator pelibatan elemen sosial lainnya, seperti; tokoh masyarakat, tokoh agama dan pengusaha, yang dapat memotovasi pencari kerja usia muda untuk memiliki usaha sendiri atau sebagi "pengusaha" dan bukan sebagai "pekerja".

Sejalan dengan hal tersebut maka dibutuhkan upaya peningkatan kapasitas pencari kerja usia muda melalui workshop; Pemetaan Sosial, penguatan kapasitas berupa perubahan paradigma "wirausaha" berbasis sumber daya setempat; dan workhsop penguatan keterampilan produksi, pengemasan dan pemasaran produksi.

Sebagai saran, ada beberapa poin penting untuk menjadi saran penelitian ini, yaitu:

1. Keluarga seharusnya menjadi pendorong lahirnya "wirausahawan" baru dari kalangan pencari kerja usia muda untuk mengubah paradigma "pencari kerja" menjadi "pemilik usaha".

2. Potensi elemen sosial seperti tokoh masyarakat, tokoh agama, pengusaha dan elemen lainnya dapat melibatkan diri sebagai wujud kepedulian terhadap penciptaan lapangan kerja baru, berupa "wirausaha baru".

3. Pihak-pihak terkait hendaknya tidak hanya menguatkan skill (keterampilan) produksi barang dan jasa kepada pencari kerja usia muda tapi lebih utama adalah penguatan perubahan paradigma wirausaha baru berbasi potensi sosial setempat.

\section{DAFTAR PUSTAKA}

Anderson, P. 2003. Asal Usul Postmodernisme. Yogyakarta: Pustaka Pelajar.

Denzin dan Lincoln. 2009. Hand Book of Qualitative Research. Penerbit: ustaka Pelajar.

Callinicos, A. 2008. Menolak Postmdernisme. Yogyakarta: Resist Book.

Castells, Manuel. 1977. The Urban Question: A Marxist Approach. London: Edward Arnold.

Habermars, Jhon. 2007. Teori Tindakan Komunikatif 1: Rasio dan Rasinalisasi masyarakat (terjemahan: Nurhadi, Judul Asli: Theories dedes Komunikativen Handelns, Band I: Handlungstrationalitat und gesellschafttliche Ratonalisierung) Jakarta: Kreasi Wacana.

Lincoln, Y Vonna S., Guba, Egon G. 1985. Naturalistik Inquiry, California: Baverley Hills: Sage Pub.

Lefebvre, Henri. 1991. The Production of Space. Translated by Donald Nicholson-Smith, Oxford: Blackwell. 2000. The Production of Space. Georgetown University Press: New York. 2002. Critique of Everyday Life,. Trans. John Moore, London and New York: Verso. . 2003. The Urban Revolution. University of Minneapolis Press: Minneapolis. 2004. Rhythmanalysis: Space, Time and Everyday Life. Continuum: London and New York.

Harvey, David. 2012. Rebel Cities: From the Right to the City to the Urban Revolution. London: Verso. Marx, Karl. 1976/1898. Capital, Vol. One, trans. Ben Fowkes. Harmondsworth, Penguin Books. 
Merrifield, A. 2006. Henri Lefebvre: A Critical Introduction. First Edition. New York: Routledge.

Moleong, J. L. 2002. Metdologi Penelitian Kualitatif. Jakarta: Rosdakarya.

Ritzer, George. 2008. Teori Sosiologi Dari Teori Sosiologi Klasik Sampai Perkembangan Mutakhir Teori Sosiologi Postmodern (terjemahan oleh: Nurhadi. Judul asli: Sociological Theory). Yogyakarta: Kreasi Wacana.

Saefullah, Asep Djaja. 1993. Pendekatan Kualitatif dan Kuantitatif Lapangan: Khususnya Dalam Studi Kependudukan. Bandung: Media Bandung.

Soja, Edward. W. 1989. Postmodern Geographies: The Reassertion of Space ini Critical Theory. London: Verso.

1996. Thirdspaces: Journeys to Los Angeles and the Rural-and-Imagined Places. Malden, Mass: Backwell.

2000. Postmetropolis: Critical Studies of Cities and Regions. Malden, Mas: Backwell.

Sugiyono. 2006. Metode Penelitian Kuantitatif Kualitatif dan R dan D. Bandung: Alfabeta 